\title{
Шляхи підвищення енергоефективності систем кондиціювання повітря в басейні
}

\author{
Н. В. Жихарєва, С. О. Бабой, Р. Е. Талибли, Н. О. Жихарєва
}

Одеська національна академія харчових технологій, вул. Канатна, 112, Одеса, 65039, Україна

\begin{abstract}
В роботі розглянуті шляхи підвищення ефективності систем кондиціювання повітря для закритих басейнів цілорічного функиіонування, розглянуті деякі технології $i$ елементи, вдосконалення яких безпосередньо підвищує енергоефективність $і$ знижує споживання електроенергії в річному ичклі використання систем кондиціювання, в які входять осушувачі повітря. Шляхами підвищення енергоефективності системи кондииіювання повітря басейну є: економічно-доичільна ізоляція, використання рекуператора, застосування байпасування та врахування нестаціонарності теплонадходження. Особливий інтерес представляє зниження добового споживання енергії та оцінка часу підготовки після функиіонування в нічному режимі очікування систем забезпечення мікроклімату в приміщенні з басейном Показані результати розрахунків за розробленою методикою, яка враховує нестаціонарні тепловологістні зовнішні та внутрішні навантаження та вплив чинників обладнання та дані рекомендації.
\end{abstract}

Ключові слова: кондиціювання повітря; басейн; рекуператор; байпасування; нестаціонарний тепломасообмін; оптимізація.

(c) The Author(s) 2017. This article is an open access publication

This work is licensed under the Creative Commons Attribution 4.0 International License (CC BY) http://creativecommons.org/licenses/by/4.0/

\section{1 Вступ}

Створення мікроклімату в приміщенні з басейном $\epsilon$ одним 3 найбільш складних завдань при розробці та реалізації системи кондиціювання i вентиляції приватного будинку.

Для зменшення випаровування рухливість повітря біля поверхні води повинна бути мінімальною. Інтенсивність випаровування залежить від площі водойми, температури води, вологості повітря, швидкості повітряного потоку i активності. Мета системи кондиціювання повітря - забезпечення комфортних умов для відвідувачів i запобігання конструкції від передчасного руйнування. Особливо важливо це в холодну пору року, коли металеві конструкції страждають від перезволоження і конденсації вологи.

Зниження споживання енергії та запобігання випаданню конденсату на стінах і вікнах приміщення 3 басейном за рахунок осушення повітря вентиляцією. У приміщенні 3 басейном потрібен особливий мікроклімат, що дозволяє людям відчувати себе комфортно. До найважливіших параметрів, що забезпечує комфорт в приміщенні 3 басейном, відноситься вологість повітря. Оптимальне значення відносної вологості повітря в приміщенні з басейном $60 \%$. Таку відносну вологість можливо забезпечити, застосовуючи спеціальні осушувачі. Для приватного басейну в приміщенні площею дзеркала води $30 \mathrm{~m}^{2}$ необхідний осушувач, споживана потужність якого 3,2 кВт. Для п'яти людей, що купаються по нормі необхідно подавати не менше $400 \mathrm{~m}^{3} /$ год свіжого повітря.
Особливістю технології створення мікроклімату в басейні $\epsilon$ боротьба 3 підвищеною вологістю в приміщенні, пов'язаної 3 випаровуванням води 3 великих площ вологої поверхні, включаючи власне дзеркало води, обхідні доріжки тощо.

Для зменшення випаровування рухливість повітря біля поверхні води повинна бути мінімальною. Нами розглянуті особливості кондиціювання повітря в басейнах, де забезпечуються комфортні умови для відвідувачів і запобігання конструкції від передчасного руйнування.

\section{2 Шляхи зниження споживання енергіi систем кондиціювання повітря в басейнах}

Нами розглянута можливість зниження споживання енергій вентиляційних агрегатів в басейнах на підігрівання і охолодження припливного повітря, а також показані способи оцінки витрати електричної енергії, споживаної електродвигунами вентиляторів.

Надані основні характеристики i показники вентиляційних агрегатів, які впливають на ефективність роботи усієї вентиляційної системи: механічна міцність, герметичність, вплив «теплових містків», коефіцієнт теплопередачі панелей корпусу, перетікання повітря в секції фільтрації та ін. При правильному проектуванні системи, що підтримує нормований рівень температури і відносної вологості в приміщеннях впродовж року i що забезпечує нормальний хімічний склад повітря (кисень, домішки i так далі), важко знаходити шляхи економії енергії на підготовку повітря. А ось електрична потужність, що витрачається на роботу блоку «двигун-вентилятор», 
може i має бути контрольованою i мінімально можливою [1,2].

Для створення певного потоку повітря необхідна витрата енергії залежить від типу вживаного вентилятора, ККД елементів цієї групи, способу передання моменту, що крутить, від валу двигуна на вал вентилятора (клино-ремінна передача знижує ККД вентиляційної групи на 4-6\%), наявності перетворювача частоти електричного струму, все частіше і частіше вживаного для підвищення ефективності роботи системи вентиляції і кондиціювання. Найважливішим показником оцінки роботи системи вентиляції $\epsilon$ показник SFP (англ. Specific Fan Power), що показує відношення споживаної потужності електричними двигунами $P$ [кВт або Вт] для створення одиничної витрати повітря $\left[\mathrm{m}^{3} / \mathrm{c}\right.$ або $\mathrm{M}^{3} /$ год] у конкретній системі механічної вентиляції [5]. Показник SFP розраховується як відношення споживаної потужності електродвигуном вентилятора до витрати повітря, переміщуваного в цій системі вентиляції. При цьому, якщо агрегат припливно-витяжний, то враховується споживана потужність двох блоків (припливного $P_{\text {прит }}$ i

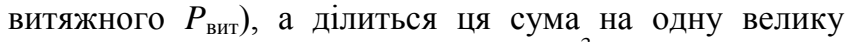
повітропродуктивність $V_{\max } \quad\left(\mathrm{BT} /\left(\mathrm{M}^{3} \cdot\right.\right.$ год)) яку, як правило, має припливний блок:

$$
S P F=\frac{p_{\text {npum }}+p_{\text {sum }}}{V_{\max }}
$$

При заданій витраті повітря і опорі мережі, розрахованої системи вентиляції для системи кондиціювання повітря, номінальна потужність електродвигуна залежить тільки від внутрішнього аеродинамічного опору агрегату (центрального кондиціонера).

При фіксованих функціональних елементах, необхідних для доведення параметрів зовнішнього повітря до необхідних кондицій, цей опір залежить від швидкостей руху повітря усередині машини. У свою чергу, швидкість повітря визначає габарити вентиляційного агрегату.

Шляхи зниження споживання енергіi систем кондиціювання повітря це.

- герметизація потоку повітря i виключення присосів навколишнього повітря i витоків обробленого повітря;

- корпус системи кондиціювання має бути добре теплоізольований щоб виключити втрати теплової енергії, витраченої на доведення параметрів повітря до потрібних перед його поданням в приміщення;

- використання в припливно-витяжної вентиляції агрегату з рекуперацією тепла;

- врахування нестаціонарних теплоприпливів.

Вимоги європейських стандартів і норм чітко упорядковують підхід до оцінки параметрів конструкції корпусів агрегатів, визначаючи найбільш важливі їх характеристики. Згідно із стандартом EN $1886: 2007$ «Ventilation for buildings». Air handling units. Mechanical performances» [5] основні характеристики корпусу класифікуються за наступними ознаками: механічній міцності (mechanical strength); герметичності корпусу (air leakage); перетіканням повітря (байпасування) в обхід фільтру усередині корпусу (filter bypass leakage); коефіцієнту теплопередачі стінок корпусу (thermal transmittance); чиннику впливу «теплових містків» (thermal bridging); міри звукоізоляції (acoustic insulation).

У Європі найбільш висококласними і оснащеними $\epsilon$ два дослідницькі центри в Німеччині TUV (Technischer Uberwachungs Verein) - це німецька авторитетна недержавна структура, яка займається питаннями технічного нагляду за продукцією, що випускається.

Стандарт EN 1886 визначає умови, методи i способи проведення випробувань як корпусу вентагрегатів центральних кондиціонерів. Деякі характеристики об'єктів визначаються на моделі досліджуваної установки, а деякі на зразку, тобто на конкретній установці, довільно вибираній вказаними дослідницькими центрами.

Як приклад розглянемо вентиляційнокондиціонуючі агрегати VTS - Ventus, які випробовувалися в німецькій лабораторії TUV Sud Munich [5]. Усі ці агрегати сертифіковані асоціацією Eurovent i їм присвоєні певні класи. По рівню механічної міцності європейський стандарт пропонує розділяти усі корпуси на три класи: D1, D2 i D3.

Основним критерієм при визначенні класу конкретного вентагрегата $\epsilon$ «максимальне відносне відхилення» (maximum relative deflection), що показує відхилення первинної позиції панелі або рами в міліметрах на метр довжини (мм/м) при дії на них певного тиску. Рівень (міра) герметичності корпусу вентустановки, тобто здатність корпусу виключити перетікання повітря або в довкілля, розділений стандартом EN 1886 на класи L1, L2 i L3.

Коефіцієнт байпасу фільтрів $K$ показує у відсотках частину «нефільтрованої» витрати повітря, тобто ту частину, що обходить фільтри. Як видно, клас вентиляційного агрегату відповідає тому максимальному класу фільтру, який може бути змонтований і ефективно працювати в цій конкретній системі вентиляції. Властивості корпусу, які ізолюють тепло, визначають здатність стінок корпусу зберігати енергію, надану повітрю в процесі його нагрівання, або ж понизити вплив теплоти ззовні до охолодженого повітря.

За стандартом EN 1886 оцінювалися два чинники: коефіцієнт теплопередачі стінок корпусу і вплив «теплових містків». Коефіцієнт теплопередачі корпусу визначається в лабораторіях шляхом випробування реального вентиляційного агрегату, працюючого за стандартними розрахунковими умовами при різниці температур повітря усередині і зовні, рівною $20{ }^{\circ} \mathrm{C}$. «Тепловими містками» вважаються частини конструкції вентиляційного агрегату, що мають підвищений коефіцієнт теплопередачі в порівнянні 3 однорідними стінками корпусу.

У цих зонах корпусу спостерігається підвищене переміщення теплових потоків. Слід пам'ятати про те, що саме в зоні «теплових містків» у вентагрегатах 3 охолодженням можливе зниження температури зовнішньої поверхні корпусу в порівнянні 3 
температурою точки роси повітря, що оточує установку i випадання конденсату. Для оцінки величини тепловтрат через «теплові містки» вводиться чинник їх впливу:

$$
K_{b}=\frac{\Delta t_{\min }}{\Delta t_{\text {air }}},
$$

де $\Delta t_{\min }=t_{\mathrm{i}}-t_{\mathrm{smax}} \epsilon$ найменшою різницею температур, $\Delta t_{\mathrm{air}}=t_{\mathrm{i}}-t_{\mathrm{a}}-$ різниця між температурами повітря усередині і зовні вентагрегата,

$t_{\mathrm{i}}$ - середня температура внутрішнього повітря;

$t_{\text {smax }}-$ максимальна температура на зовнішній поверхні;

$t_{\mathrm{a}}-$ середня температура зовнішнього повітря.

Будь-яка частина поверхні корпусу, яка піддається дії зовнішнього повітря, вважається зовнішньою поверхнею. Клас теплових містків відповідає зміні на 3 ${ }^{\circ} \mathrm{C}$ максимальної температури поверхні при різниці температур $20^{\circ} \mathrm{C}$ (максимальна погрішність вимірів температури на поверхні $\left.\pm 0,2{ }^{\circ} \mathrm{C}\right)$.

Рівень акустичної ізоляції корпусу визначається випробуваннями, які проводяться на моделях установок, що мають розміри відповідно до вимог стандарту EN 1886 [4,5].

\section{3 Результати досліджень}

В роботі показано, що більшу частину холодного періоду можна сушити повітря в приміщенні 3 басейном, використовуючи загальнообмінну припливно-витяжну вентиляцію, робота якої обумовлена необхідністю подачі свіжого повітря для дихання людей. Таким чином, в холодний період можна, не включаючи спеціальний осушувальний агрегат, забезпечувати необхідну відносну вологість $60 \%$ за рахунок роботи припливно-витяжної вентиляції. Для кліматичних умов м. Одеси осушку вентиляцією можна виробляти до зовнішньої температури $19-22^{\circ} \mathrm{C}$. При більш високих температурах зовнішнього повітря надходження вологи 3 припливним повітрям починає превалювати над кількістю вологи повітря, що видаляється витяжною вентиляцією. Це додаткова кількість вологи разом з вологою, що випаровується 3 дзеркала басейну, в цей період має віддалятися спеціальним компресорно-конденсаційним осушувачем.

Проведений аналіз інтенсивності випаровування в басейні за допомогою програми, де враховується $W_{\text {isp }}$ ${ }^{\prime} W_{\text {udp }}$, де $W_{\text {isp }}$ кількість води, що випаровується 3 поверхні води басейну як функція відносної вологості повітря в приміщень 3 басейном, $W_{\text {udp }}-$ кількість вологи, що видаляється припливно-витяжною вентиляцією, як функція відносної вологості в приміщень.

3 графіку, наведеному на рисунку 1, видно що квазістаціонарна рівність настає коли відносна вологість відповідатиме у перехідний період $\varphi=60 \%$, у холодний $\varphi=49 \%$. У теплий період, як показано на рисунку $3, \quad \varphi>60 \%, \quad \mathrm{t}_{3 о в}=36^{\circ} \mathrm{C}$ необхідно використовувати осушувач повітря коли температура у приміщенні з басейном перевищить $30{ }^{\circ} \mathrm{C}$. У цей період кількість вологи, яка виноситься витяжною вентиляцією буде дорівнювати кількості вологи, яка поступає в приміщення 3 повітрям 3 припливної вентиляції. Виходячи з отриманого значення відносної вологості, яке необхідно підтримувати для квазістаціонарної рівноваги, що встановилася, можна точно визначити кількість повітря, яке необхідно подавати i видаляти 3 приміщення. Далі можна підібрати оптимальне устаткування для осушення повітря в приміщень басейну.

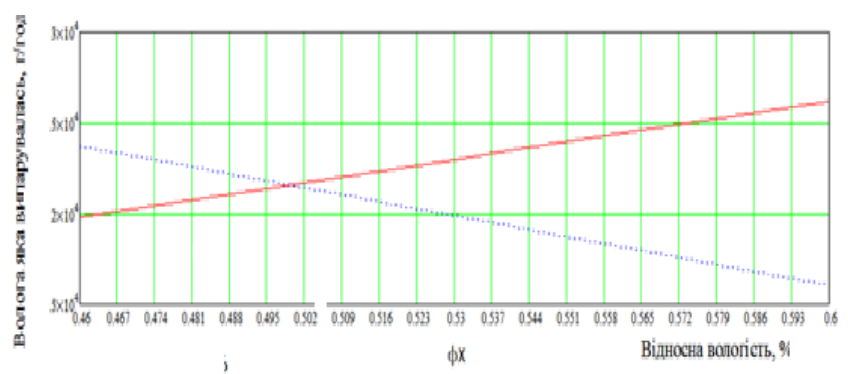

Рисунок 1 - Інтенсивність випаровування вологи у перехідний період.

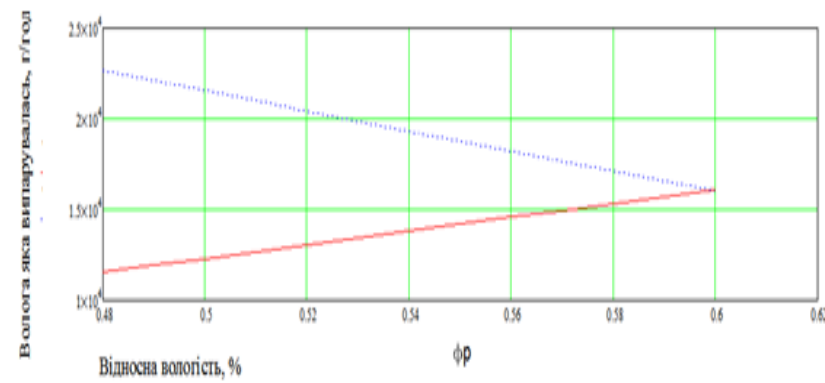

Рисунок 2 - Інтенсивність випаровування вологи у холодний період року

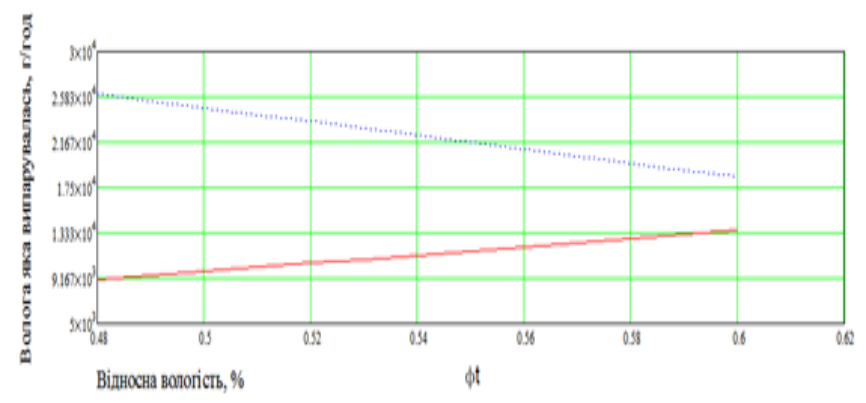

Рисунок 3 - Інтенсивність випаровування вологи у теплий період року

Особливий інтерес представляє зниження добового споживання енергії та оцінка часу підготовки після функціонування в нічному режимі очікування систем забезпечення мікроклімату в приміщенні 3 басейном $[1,3]$. Після закінчення використання басейну можна закрити дзеркало води спеціальною плівкою i допустити збільшення відносної вологості в приміщенні до 65-70\%. Це можна зробити в ручному режимі або при використанні програм і регульованого контролера. Додаткова автоматика, включаючи датчики присутності людей, окупається протягом 2-3 років за рахунок економії енергії в черговому режимі, коли 
басейн затягується плівкою, вимикається спеціальний осушувач і зменшується або припиняєься вентиляція зовнішнім повітрям. Так наприклад, добова економія електроенергії для умов м. Одеси при встановленій в черговому режимі припливно-витяжної вентиляції (тривалість чергового режиму 10 годин) і зовнішній температурі $t_{\mathrm{H}}=18{ }^{\circ} \mathrm{C}$ залишить за 10 годин більше 80 кВг. Нагрівач споживає 7,9 кВт і вентилятори 0,3 кВт. Якщо вентиляція поєднана 3 системою повітряного опалення, то опалення вимикати не можна, може утворитися конденсат на огорожах (стінах і вікнах).

\section{Висновок}

Враховуючи шляхи підвищення ефективності систем кондиціювання повітря для критих басейнів показано, що економію енерговитрат можна отримати, використовуючи в припливно-витяжної вентиляції агрегат с рекуперацією тепла та 3 застосуванням байпасу $[2,4,5]$. Застосування такої системи дозволить при температурі зовнішнього повітря і умовах м. Одеси економити понад 4 кВт потужності калорифера. Необхідно відзначити, що при підвищенні зовнішньої температури кількість тепла, передане приточування в рекуператорі, буде падати, але при цьому зменшиться i потрібна потужність нагрівача. При температурах зовнішнього повітря вище $28{ }^{\circ} \mathrm{C}$ з'явиться необхідність охолоджувати припливне повітря, проте рекуператор буде зменшувати необхідну холодопродуктивність кондиціонера осушувача. Зрозуміло, що при температурах зовнішнього повітря вище $28^{\circ} \mathrm{C}$ теплова потужність, що відводиться від припливного повітря, буде істотно нижче, ніж теплова потужність, що передається йому в зимовий час через набагато більш високу різницю температур між внутрішнім і зовнішнім повітрям. Однак зменшення необхідної холодопродуктивності кондиціонера в окремих випадках може дозволити використовувати кондиціонер меншого типономінала, ніж кондиціонер без рекуператора. Різниця в ціні таких кондиціонерів може скласти істотну частину вартості і таким чином знизити термін його окупності на 1-2 роки.

Показано, що використання повітряних систем опалення для обігріву басейну та суміжних приміщень термін окупності рекуператора зазвичай не перевищує 3-4х років.

Встановлено також, що має ефект зниження добового споживання енергії та оцінка часу підготовки після функціонування в нічному режимі очікування систем забезпечення мікроклімату в приміщенні 3 басейном.

Проведений аналіз шляхів підвищення ефективності систем кондиціювання повітря дозволяє проводити зіставлення альтернативних варіантів систем кондиціювання повітря при їх оптимізації.

\section{Литература}

1. Перепека В.И., Жихарева Н.В. Расчеты систем кондиционирования и вентиляции. Одесса: «ТЭС», 2014. $-340 \mathrm{c}$.

2. Антонов П.П. Методика расчета и проектирования систем обеспечения микроклимата в помещениях плавательных бассейнов.- М.: ООО «СИ- ТЭС-Кондиционер», 2005.- 21 с.

3. Жихарсва Н.В. Методика розрахунку систем кондиціювання повітря басейнів //Холодильна техніка і технологія, 2015.- № 51(4).- С. 12-16.

4. Kogut, V.E., Butovskyi, I. D., Zhikhareva N.V., Khmelniuk M.G. Anticipated costeffective effect from application of the ejector heat exchanger for condensation of light fraction hydrocarbon on the petroleum storage depot. Refrigeration Engineering and Technology, 2016, No. 52 (3). - P. 25-28.

5. Жихарєва Н.В. Хмельнюк М.Г. Математичне моделювання нестаціонарного теплообміну примішень / Н.В. Жихарєва, М.Г. Хмельнюк // Холодильна техніка та технологія, 2016. -Том. 52, № 6. - С. 71-77.

\title{
Ways to improve the energy efficiency of air-conditioning systems of swimming pools
}

\author{
N. V. Zhykhareva, E. O. Baboy, R. E. Talybly, N. O. Zhykhareva \\ Odessa National Academy of Food Technologies, 112 Kanatnaia str., Odessa, 65039, Ukraine
}

The paper considers the ways to improve the efficiency of air-conditioning systems for year-round functioning indoor pools, as well as some technologies and elements, the improvement of which directly increases energy efficiency and reduces electricity consumption in the annual cycle of air conditioning systems with dehumidifiers utilization. The ways of improvement of the pool air conditioning system energy efficiency are: economical and integral isolation, recuperator use, the use of bypassing and heat transfer unsteadiness consideration. Particular interest is the reduction of daily energy consumption and the assessment of the preparation time of after nighttime operation of the microclimate maintenance systems in the room with the pool. Based on the developed method which takes into consideration the unsteady heat flows and the influence of equipment factors the results of calculations are shown and some recommendations are given.

Key words: air conditioning, swimming pool, recuperator, bypass, non-stationary heat and mass transfer, optimization. 


\section{References}

1. Perepeka V.I., Zhykhareva N.V. (2014) The calculations of air conditioning and ventilation. Odessa «EC», $340 \mathrm{p}$.

2. Antonov P.P. (2005) Metodika calculation and design systems to ensure indoor climate swimming pools. Moscow, OOO «CI-TES-Conditsioner», $21 \mathrm{p}$.

3. Zhykhareva N.V. (2016) Swimming pools airconditioning systems calculation methods. Refrigeration Engineering and Technology, 51(4), 12-16. DOI: $10.15673 / 0453-8307.4 / 2015.39284$
4. Kogut, V.E., Butovskyi, I. D., Zhykhareva N.V., Khmelniuk M.G. (2016) Anticipated cost effective effect from application of the ejector heat exchanger for condensation of light fraction hydrocarbon on the petroleum storage depot. Refrigeration Engineering and $\begin{array}{llll}\text { Technology, } & 52 & \text { (3), } & \text { 25-28. }\end{array}$ DOI: http://dx.doi.org/10.15673/ret.v52i3.119

5. Zhikhareva N.V. Khmelniuk M.G. (2016) Mathematical modeling of building unsteady heat transfer. Refrigeration Engineering and Technology, 52 (6), 75-79. DOI: http://dx.doi.org/10.15673/ret.v52i6.479 